\title{
Graptemys ernsti Lovich and McCoy 1992 - Escambia Map Turtle
}

\author{
JefFrey E. Lovich ${ }^{1}$, James C. Godwin², and C.J. MCCoY ${ }^{3}$ \\ ${ }^{1}$ U.S. Geological Survey, Southwest Biological Science Center, 2255 North Gemini Drive \\ MS-9394, Flagstaff, Arizona 86001 USA [jeffrey_lovich@usgs.gov]; \\ ${ }^{2}$ Alabama Natural Heritage Program, Environmental Institute, 1090 S. Donahue Drive, \\ Auburn University, Alabama 36849 USA [jcg0001@auburn.edu]; \\ ${ }^{3}$ Deceased, formerly: Carnegie Museum of Natural History, 4400 Forbes Ave., \\ Pittsburgh, Pennsylvania 15213 USA
}

\begin{abstract}
Summary.-The Escambia Map Turtle, Graptemys ernsti (Family Emydidae) is a large freshwater species endemic to rivers of the Pensacola (Escambia) and Choctawhatchee Bay drainages of southeastern Alabama and western Florida, USA. It was previously recognized as part of the composite species Graptemys pulchra (see Lovich and McCoy 1992). Sexual dimorphism is pronounced, with adult females (carapace length [CL] to $285 \mathrm{~mm}$ ) attaining more than twice the size of adult males (CL to $131 \mathrm{~mm}$ ). Although the species is locally abundant, populations are threatened by habitat destruction coupled with declines in their prey base, commercial collecting, and vandalism. The current IUCN Red List status is Near Threatened, assessed as of 2010. With the recent discovery of a population in the Choctawhatchee River, genetic and morphological studies are needed to examine possible variation. Additionally, the presence of $G$. barbouri within the Choctawhatchee River presents a unique opportunity to study the ecological relations of sympatric megacephalic Graptemys.

Distribution.-USA.Restricted to the Escambia,Yellow,Conecuh,Shoal,Pea, and Choctawhatchee River systems emptying into Pensacola and Choctawhatchee Bays in Alabama and western Florida.

SynONYMY. - Graptemys ernsti Lovich and McCoy 1992, Graptemys pulchra ernsti.

SubSPECIES. - None recognized.

Status. - IUCN 2011 Red List Status: Near Threatened (NT) (assessed 2010); CITES: Appendix III (as all Graptemys spp.; USA); US ESA: Not Listed.
\end{abstract}

Taxonomy. - The Escambia Map Turtle was described by Lovich and McCoy (1992), who along with Ennen et al. (2010) demonstrated that what was originally referred to as Graptemys pulchra Baur was a composite that consisted of four distinct, allopatric species. The other species in the complex include G.pulchra (sensu stricto) of rivers tributary to the Mobile Bay Drainage in Alabama and northwestern Georgia, and G. gibbonsi (Lovich and McCoy 1994a; Lovich et al. 2009) in the Pascagoula River in Mississippi, and G. pearlensis (Ennen et al. 2010) in the Pearl River of

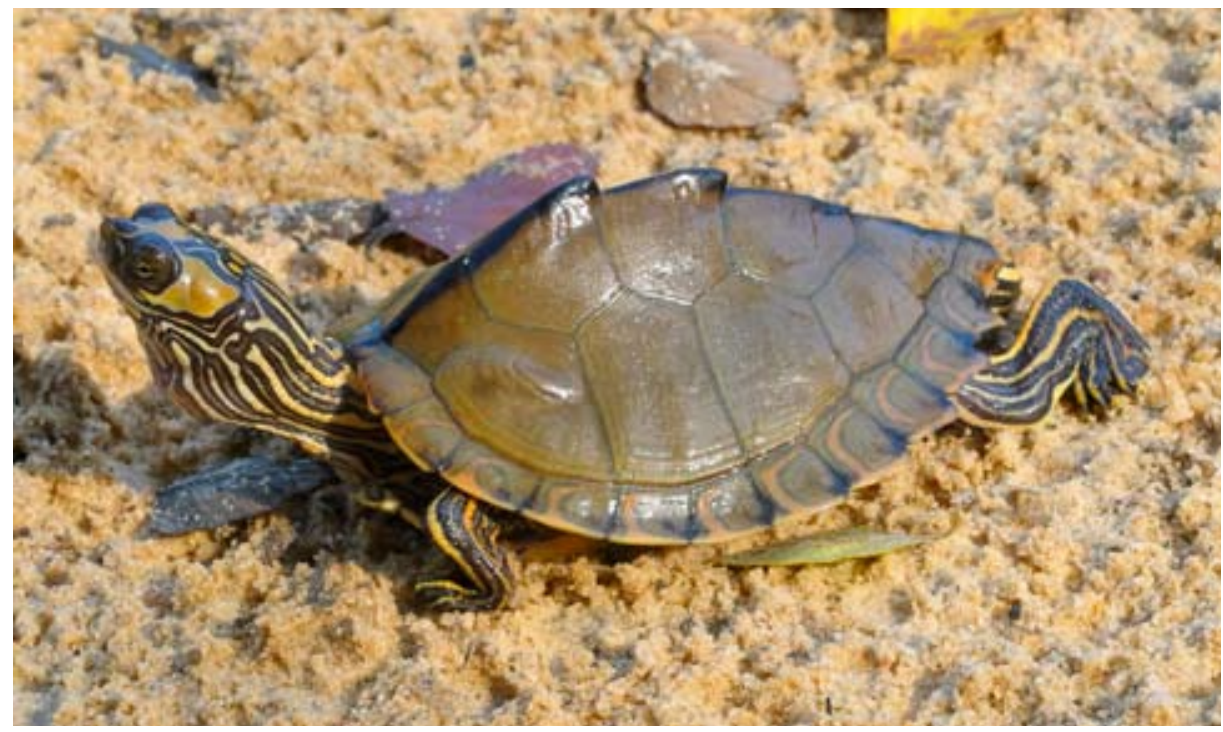

Figure 1. Young mature male Graptemys ernsti from the Yellow River, Covington County, Alabama. The coloration of the dorsal and lateral head blotch is typical for the species and a portion of the nasal trident may be seen. Note the bulge on the \#1 pleural, a character that G. ernsti often exhibits, especially in smaller specimens. Photo by James C. Godwin. 


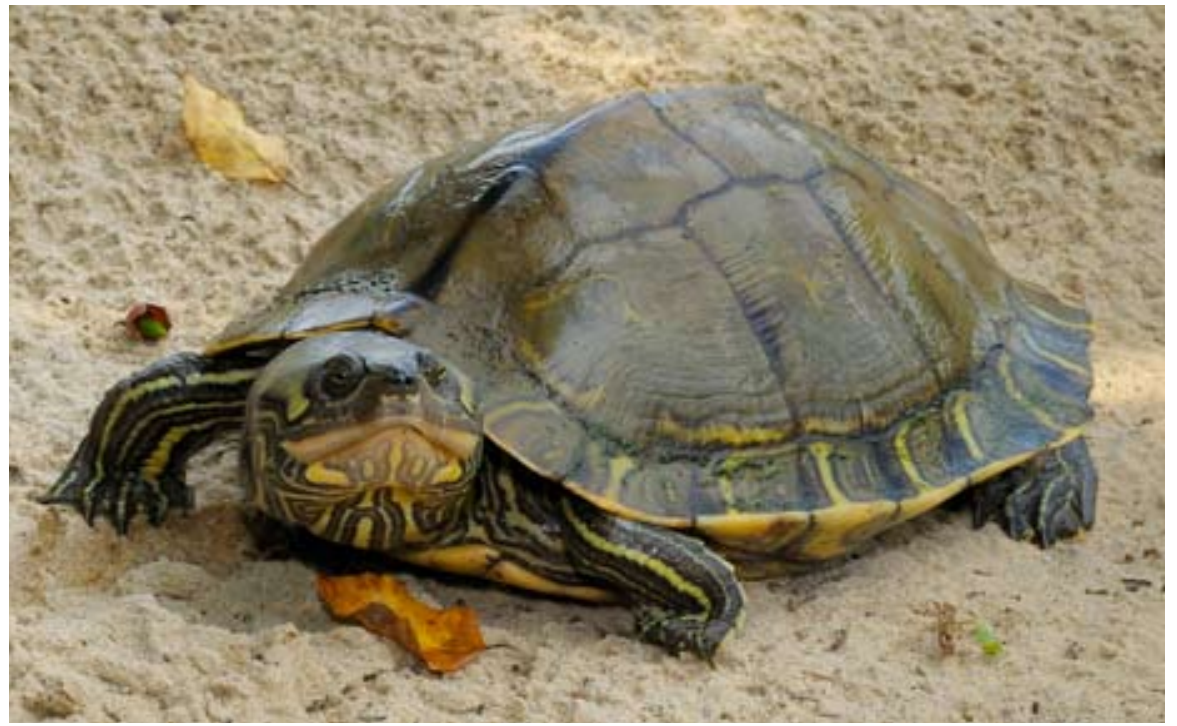

Figure 2. Adult female Graptemys ernsti from the Conecuh River, Covington County, Alabama. The broad head and jaw structure, identifying G. ernsti as one of the megacephalic species, are evident, as is the ventral chin pattern. Photo by James C. Godwin.

Mississippi and eastern Louisiana. The four species are welldifferentiated on the basis of morphology and pattern, and exhibit divergent mitochondrial DNAgenotypes (Lambetal. 1994). These four species, together with G. barbouri, form the Graptemys pulchra species group of the genus (Lovich and McCoy 1992). Species in this complex exhibit extreme sexual size dimorphism, and females develop broad heads (megacephaly) with expansive mandibular and maxillary crushing surfaces (Lindeman 2000). Additional information on G. ernsti was summarized by Lovich (1985 [as G. pulchra, part]) and by Lovich and McCoy (1994b).

Description. - The Escambia Map Turtle is a large (to $285 \mathrm{~mm} \mathrm{CL}$ ) turtle. The shell is high-domed, possesses a median keel, and has relatively wide yellow bars on the dorsal surface of the marginal scutes. The median carapace

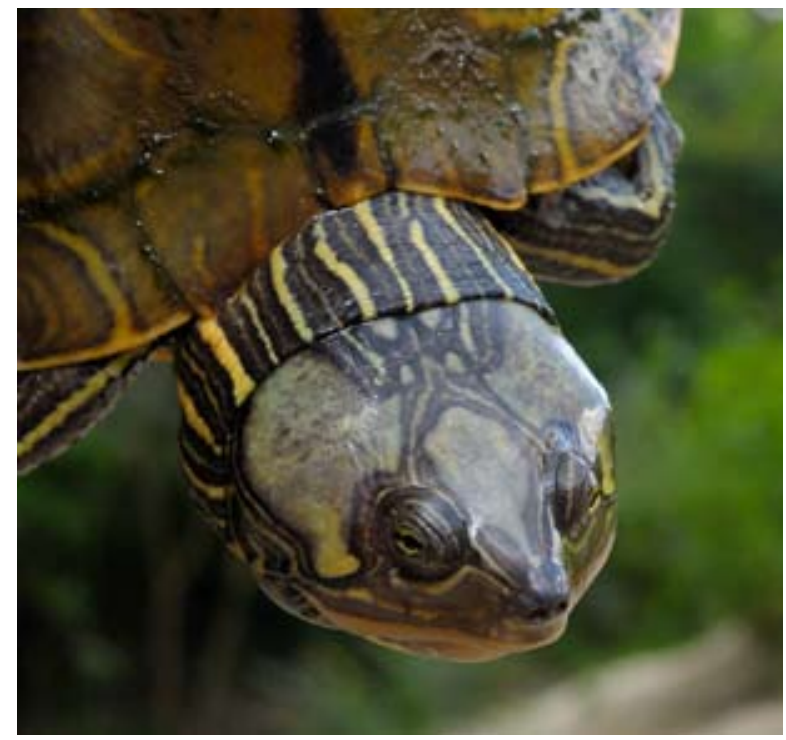

Figure 3. Dorsal head pattern of an adult female Graptemys ernsti from the Conecuh River, Covington County, Alabama. As females age their head coloration becomes muted, but the nasal trident is still evident. Photo by James C. Godwin. keel is composed of salient spines on the posterior portions of the second and third vertebrals. Old females frequently appear "hump-backed" due to dramatic anterior-posterior incline of the first vertebral scute. A broken black stripe, most pronounced anteriorly, marks the median keel of the vertebrals, and each pleural scute has wide yellow rings and vermiculations on the distal part. The plastron is pale yellow with seam-following dark pigment, particularly on transverse seams. Ground color of head and limbs is brown to olive with light yellow or yellowish-green stripes and blotches. The head pattern consists of a large interorbital blotch that is not connected to the large postorbital blotches. Supraoccipital spots are usually present and may be fused with the dorsal paramedian neck stripes. A three-pronged yellow blotch (nasal trident) is present on the dorsal head surface behind the nares.

Adult females can be over twice the size of adult males (mean female $\mathrm{CL} /$ mean male $\mathrm{CL}=1.66$, including imma-

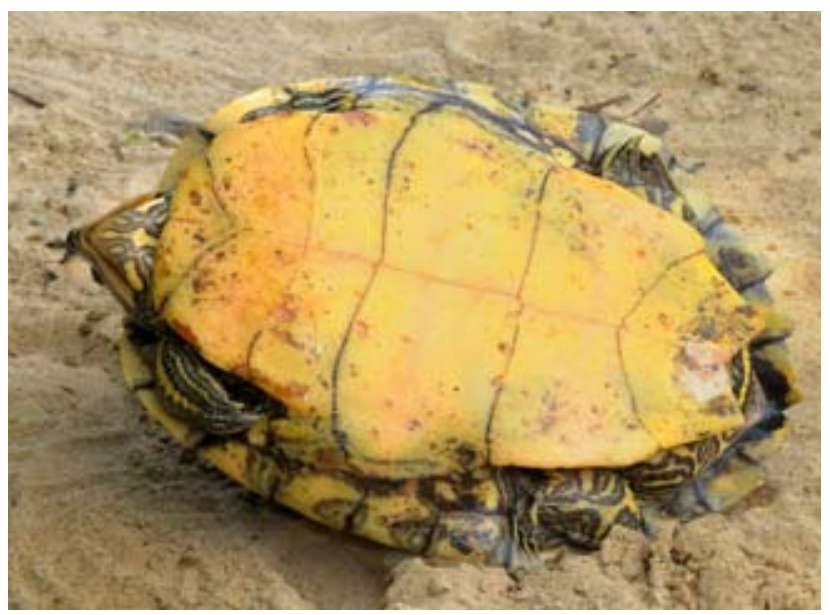

Figure 4. Plastral pattern of an adult female Graptemys ernsti from the Conecuh River, Covington County, Alabama. Photo by James C. Godwin. 


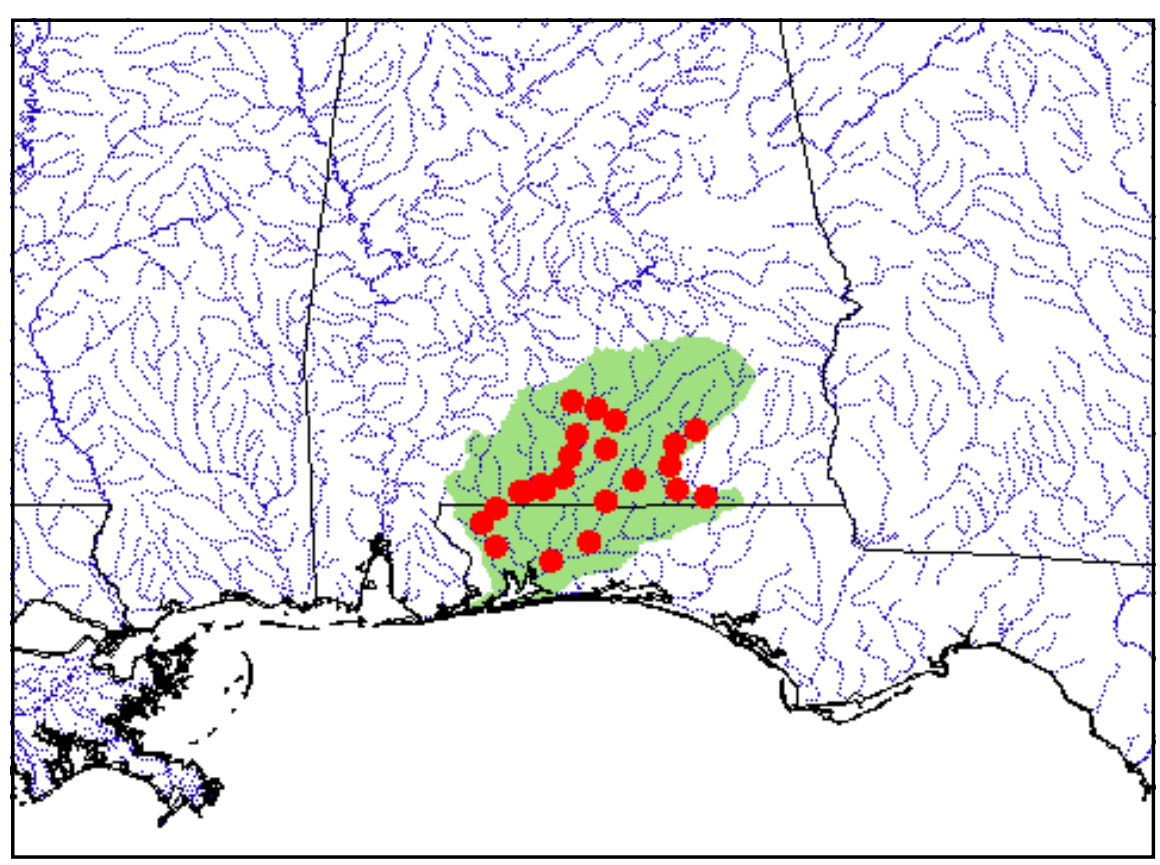

Figure 5. Distribution of Graptemys ernsti in Alabama and Florida, USA. Red dots = museum and literature occurrence records of native populations based on Iverson (1992) as part of $G$. pulchra sensu lato, plus more recent and authors' data; green shading = projected distribution based on GIS-defined hydrologic unit compartments (HUCs) constructed around verified localities and then adding HUCs that connect known point localities in the same watershed or physiographic region, and similar habitats and elevations as verified HUCs (Buhlmann et al. 2009), and adjusted based on authors' data.

tures), and have conspicuously enlarged heads with broad jaw surfaces. Males have longer tails with the vent posterior to the rim of the carapace. Both sexes have relatively flat plastrons.

Allopatric species in the G.pulchra species group differ as follows: G. pulchra has the interorbital and postorbital blotches connected, concentric yellow circles on the dorsal sides of marginal scutes, and lacks supraoccipital spots and nasal trident; G. gibbonsi and G. pearlensis have the interorbital and postorbital blotches connected, nasal trident usually present, and no supraoccipital spots; G. barbouri has a narrow interorbital blotch that ends in a point on the rostrum, and a transverse bar on the lower jaw (Ernst et al. 1994; Ernst and Lovich 2009, Ennen et al. 2010).

Distribution. - The Escambia Map Turtle is found primarily in large to medium-sized rivers emptying into Escambia Bay, including the Conecuh, Escambia, Yellow,
Shoal, Pea, and Choctawhatchee Rivers in southern Alabama and western Florida, USA. Basking individuals have been observed in the Sepulga River and tributaries such as Persimmon and Pigeon Creeks (Godwin, pers. obs.). Graptemys ernsti is apparently absent from the blackwater streams within its comprehensive range, as these streams lack native mollusc populations due to high tannin levels. These include the Blackwater and Perdido Rivers, and Big Escambia Creek.

Habitat and Ecology. - This species is most abundant in large rivers, where basking sites (i.e., logs and snags), nesting sites (i.e., sandy beaches), and food species (especially clams and snails) are abundant. The species is apparently tolerant of organic pollution, and maintains populations in areas contaminated by sewage. Saltwater is avoided, and populations do not occur within a mile of estuaries (Shealy 1992).
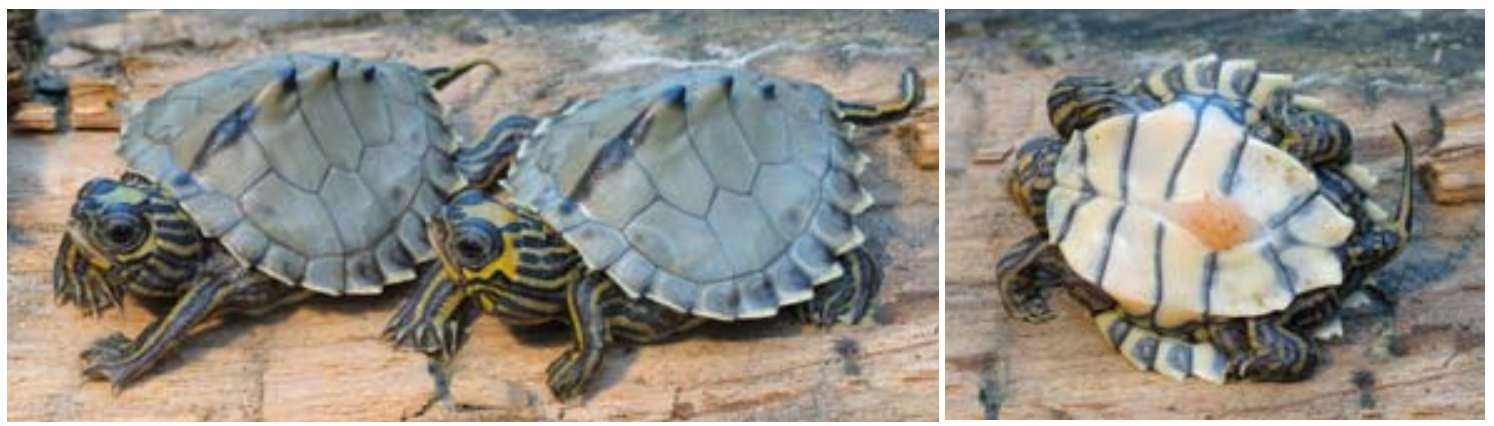

Figure 6. Left: A pair of hatchling Graptemys ernsti from the Conecuh River, Covington County, Alabama. Note the difference in coloration of the head pattern in clutch mates, with one being a bit more vibrant than the other. Right: Plastral pattern of a hatchling $G$. ernsti from the Conecuh River, Covington County, Alabama. Photos by James C. Godwin. 


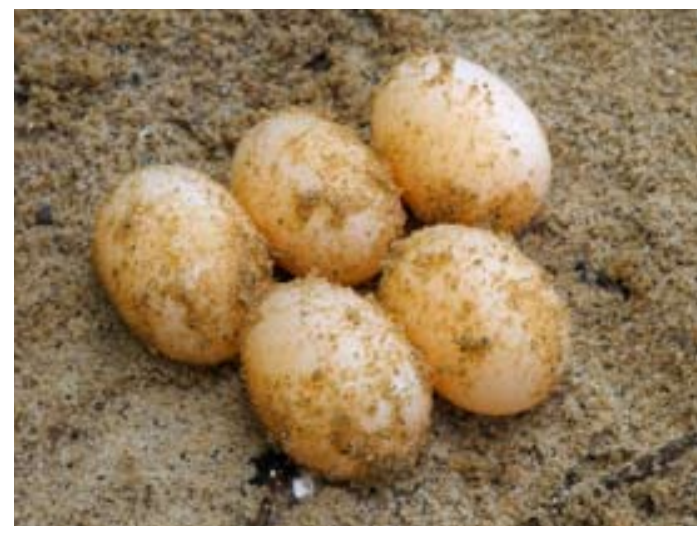

Figure 7. A clutch of five freshly laid and excavated eggs of Graptemys ernsti from the Conecuh River, Covington County, Alabama. Photo by James C. Godwin.

The introduced Asian clam (Corbicula sp.) may be an important food source for the species, especially for adult females which have broad crushing jaw surfaces. Adult females also eat native clams, snails, and crustaceans (Shealy 1976). Individuals less than $100 \mathrm{~mm}$ CL are insectivorous, as are adult males. A captive-retained adult female (CL $245 \mathrm{~mm}$ ) from the Pea River passed shell fragments of the native clams Lampsilis teres and Villosa lienosa (Godwin, pers. obs.).

Graptemys ernsti is primarily diurnal, and is most active from mid-April to late October when water temperatures exceed $19^{\circ} \mathrm{C}$. Basking is the most conspicuous surface activity, and occurs at all times of the day. Hatchling and juvenile turtles prefer protected bask sites, such as the interior of a cluster of branches, while adult male and female turtles bask in more open settings over deep water.

Shealy (1976) reported that the peak of nesting occurs in June. Average clutch size is 7.2 eggs, and average estimated clutches per season is four. The largest (and oldest) females are capable of producing six or seven clutches annually, with a total annual reproductive potential of 71 (Shealy 1976). Nest sites are 3-15 m from the water's edge on a sand bar, and 2-3 $\mathrm{m}$ above water level. Incubation requires 74-79 (average 76) days. Sexual maturity is reached in about 14 years in females, and 3 years in males. Maximum size in

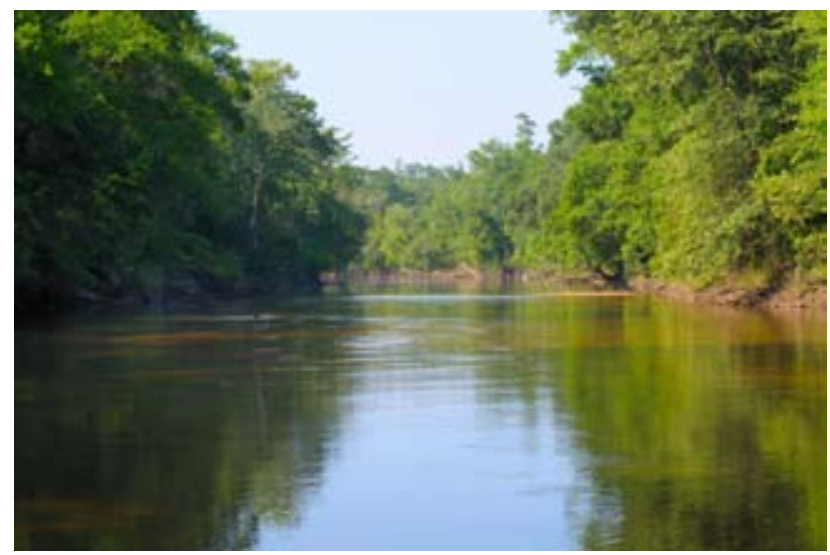

Figure 8. Yellow River in Covington County, Alabama, representative habitat of Graptemys ernsti. Photo by James C. Godwin. females is reached in about 23 years, and longevity probably exceeds 50 years (Shealy 1978).

Shealy (1976) estimated population density of G.ernsti in the Conecuh River, Alabama, as one turtle per 3-4 m of river length. Graptemys ernsti was the most abundant turtle species at that site, where it occurred with (in order of decreasing abundance) Apalone spinifera, Pseudemys concinna, A. mutica, Sternotherus minor, Macrochelys temminckii, and Trachemys scripta. Within the Escambia River drainage $G$. ernsti is the only species of Graptemys; however, within the Choctawhatchee River system, it is sympatric with $G$. barbouri (Godwin 2002).

Population Status. - No published information is available on the current population status of this species. Shealy (1976) studied a population in the Conecuh River, Alabama, where it was locally abundant, and estimated a density of 3-4 per $\mathrm{m}$ within one $500 \mathrm{~m}$ stretch of the river. Shealy $(1978,1992)$ reported the species as "relatively abundant in restricted areas" in the Escambia River, Florida. Aresco and Shealy (2006) observed a density of 5.0 turtles per river $\mathrm{km}$ on the Escambia River in Florida. Godwin (2000, 2002) surveyed basking Graptemys and reported an overall mean basking density for the Conecuh system of 5.9 turtles per river $\mathrm{km}$, but overall numbers were quite variable. Mean basking turtle counts per river $\mathrm{km}$ were highest on the mainstem of the Conecuh River (12.3) followed by Patsaliga Creek (3.1), Sepulga River (1.8), and Yellow River (0.8). Lowest observed counts were in the Choctawhatchee and Pea Rivers with average basking turtles per river $\mathrm{km}$ of 0.2 and 0.4 , respectively.

Threats to Survival. - Nest mortality rates may exceed $95 \%$, the primary nest predators being fish crows (Corvus ossifragus) and raccoons (Procyon lotor). Unregulated allterrain vehicular (ATV) usage on sandbars and river banks may destroy nests, kill hatchlings, and result in deep tire ruts that may impede hatchling movements when travelling to the water (Aresco and Shealy 2006).

Few $G$. ernsti are found in streams supporting scant mollusc populations, and none are found in streams in which molluscs are entirely absent (Shealy 1976). Thus, any form of stream pollution that has an impact on mollusc populations would also be detrimental to populations of $G$. ernsti, and threats to the mollusc fauna undoubtedly affect G. ernsti. Within the range of the Escambia Map Turtle, 32 species of native unionid clams have been reported and of these 13 have undergone notable declines and one has been extirpated (Williams et al. 2008).

Habitat modifications such as removal of logs or snags, channelization, or impoundment may eliminate habitat elements such as basking sites and nesting beaches that are essential for survival of this species. A proposed hydroelectric dam on the Yellow River in Okaloosa County, Florida, would create a large reservoir and alter the natural hydrology of the river, both upstream and downstream from the dam (Aresco and Shealy 2006).

Hatchlings of Graptemys species are popular pets, and many enter the pet trade through uncontrolled commercial 
collecting. The only significant predators of adults are people. Local fishermen incorrectly regard turtles as vermin, or competitors for fish. Shooting basking turtles, a common practice in some areas, may significantly reduce populations.

Conservation Measures Taken. - The Escambia Map Turtle (as the Alabama Map Turtle, G. pulchra, in part) is classified as a Species of Special Concern in Alabama. This classification is based on the premise that the species "must be continually monitored because of imminent threats to the habitat, limited range in Alabama, or because of other physical or biological factors that may cause them to become threatened or endangered within the state in the foreseeable future" (Marion 1986). With the description of G.ernsti, the species was added to the Alabama Department of Conservation and Natural Resources' Nongame Species Regulation list. Commercial, scientific collecting, or possession of the Escambia Map Turtle in Alabama, without a permit from the Department of Conservation and Natural Resources, is prohibited.

In Florida, the Escambia Map Turtle (as the Alabama Map Turtle) was formerly classified as a rare species (Shealy 1992). Rare species are defined as species that are "potentially at risk because they are found only within a restricted geographic area or habitat in the state" (Moler 1992). Effective 20 July 2009, the state of Florida banned the commercial harvest or sale of freshwater turtles from the wild, including turtle eggs. The ruling also prohibits the collection and possession of any state imperiled freshwater turtle. The Escambia Map Turtle is not protected under this designation as an imperiled species, but Barbour's map turtle (G. barbouri) is, and because of similarity of appearance, G. ernsti is thus afforded protection (Florida Fish and Wildlife Conservation Commision 2010). Under the Alabama Natural Heritage Program and Florida Natural Areas Inventory, the species is listed as G2 (Imperiled) and State S2 (Imperiled).

Conservation Measures Proposed. - Marion (1986) suggested several conservation measures for the species in Alabama, including protecting and improving the water quality of rivers and streams occupied by this species, discouraging stream channelization and removal of snags, prohibiting or further regulating commercial collecting, and monitoring densities of existing populations. In Florida, similar recommendations for water quality maintenance and population monitoring have been made (Shealy 1992). Aresco and Shealy (2006) suggested that use of ATVs in nesting areas should be prohibited between the nesting and hatching seasons. With the recent ban on commerical harvest in Florida, populations could be monitored in both Florida and Alabama to ensure that illegal trade is not occuring.

Captive Husbandry. - Most species of Graptemys do well in captivity (Wahlquist 1970). Captive specimens of molluscivorous Graptemys can be successfully maintained on an artificial mollusc diet composed of a mixture of bone meal, oyster shell, trout chow, and agar (R.C. Vogt, pers. comm.). Captives are known to court and reproduce regularly
(A. Redmond, pers. comm.), and may live in captivity for over 15 years (Snider and Bowler 1992).

Current Research. - The study of Shealy (1976) contains the only detailed ecological data available on Graptemys ernsti. Additional studies in other parts of the species' range are needed to establish baseline data on distribution and especially population abundance.

\section{LITERATURE CITED}

ARESCO,M.J.ANDSHEALY,R.M.2006.Graptemysernsti-Escambiamap turtle. In: Meylan, P.A. (Ed.). Biology and Conservation of Florida Turtles. Chelonian Research Monographs 3, pp. 273-278.

Buhlmann, K.A., Akre, T.S.B., Iverson, J.B., Karapatakis, D., Mittermeier, R.A., Georges, A., Rhodin, A.G.J., van DiJK, P.P., AND GibBons, J.W. 2009. A global analysis of tortoise and freshwater turtle distributions with identification of priority conservation areas. Chelonian Conservation and Biology 8(2):116-149.

EnNen, J.R.,Lovich, J.E., Kreiser, B.R., Selman, W., And Qualls, C.P. 2010. Genetic and morphological variation between populations of the Pascagoula map turtle (Graptemys gibbonsi) in the Pearl and Pascagoula rivers with description of a new species. Chelonian Conservation and Biology 9:98-113.

ERnst, C.H. AND Lovich, J.E. 2009. Turtles of the United States and Canada, Second Edition. Baltimore: Johns Hopkins University Press, $827 \mathrm{pp}$.

ERnst, C.H., Lovich, J.E., AND Barbour, R.W. 1994. Turtles of the United States and Canada. Washington, D.C.: Smithsonian Institution Press, 578 pp.

Florida Fish and WildLife Conservation Commision. 2010. Freshwater turtles. (http://myfwc.com/wildlifehabitats/SpeciesInfo_FreshwaterTurtles.htm).

GoDwIN, J.C. 2000. Escambia map turtle (Graptemys ernsti) status survey. Unpublished report submitted to the Alabama Department of Conservation and Natural Resources, Division of Wildlife and Freshwater Fisheries, 13 pp.

GoDwIN, J.C. 2002. Distribution and status of Barbour's map turtle (Graptemys barbouri) in the Choctawhatchee River System, Alabama. Unpublished report submitted to the Alabama Department of Conservation and Natural Resources, Division of Wildlife and Freshwater Fisheries, $21 \mathrm{pp}$.

IvERSON, J.B. 1992. A Revised Checklist with Distribution Maps of the Turtles of the World. Richmond, IN: Privately published, $363 \mathrm{pp}$.

LAMB, T., LydEARD, C. WALKER, R.B., AND GibBOnS, J.W. 1994. Molecular systematics of map turtles (Graptemys): a comparison of mitochondrial restriction site versus sequence data. Systematic Biology 43(4):543-559.

LinDEMAN, P.V. 2000. Evolution of the relative width of the head and alveolar surfaces in map turtles (Testudines: Emydidae: Graptemys). Biological Journal of the Linnean Society 69:549-576.

Lovich, J.E. 1985. Graptemys pulchra Baur. Alabama map turtle. Catalogue of American Amphibians and Reptiles 360.1-360.2.

Lovich, J.E. AND McCoy, C.J. 1992. Review of the Graptemys pulchra group(Reptilia,Testudines,Emydidae), withdescriptions of two new species. Annals of Carnegie Museum 61(4):293-315.

Lovich, J.E. AND McCoy, C.J. 1994a. Graptemys gibbonsi. Catalogue of American Amphibians and Reptiles 586.1-586.2.

Lovich, J.E. AND McCoy, C.J. 1994b. Graptemys ernsti. Catalogue of American Amphibians and Reptiles 585.1-585.2.

Lovich, J.E., Selman, W., AND McCoy, C.J. 2009. Graptemys gibbonsi Lovich and McCoy 1992 - Pascagoula map turtle, Pearl River map turtle, Gibbon's map turtle. In: Rhodin, A.G.J., Pritchard, P.C.H., 
van Dijk, P.P., Saumure, R.A., Buhlmann, K.A., Iverson, J.B., and Mittermeier,R.A.(Eds.).Conservation biology of freshwater turtles and tortoises: a compilation project of the IUCN/SSC Tortoise and FreshwaterTurtleSpecialistGroup.Chelonian Research Monographs No. 5, pp. 029.1-029.8. doi:10.3854/crm.5.029.gibbonsi.v1.2009, http://www.iucn-cbftt/.

MARION, K.R. 1986. Alabama map turtle. In: Mount, R.H. (Ed.). Vertebrate animals of Alabama in need of special attention. Alabama Agricultural Experiment Station, Auburn, Alabama, pp. 50-52.

MOLER, P.E. (Ed.). 1992. Rare and endangered biota of Florida. Volume III, amphibians and reptiles. Gainesville: University Press of Florida, $291 \mathrm{pp}$.

SHEALY, R.M. 1976. The natural history of the Alabama map turtle, Graptemys pulchra Baur, in Alabama. Bulletin of the Florida State Museum, Biological Sciences Series 21(2):47-111.

SHEALY, R.M. 1978. Alabama map turtle. In: McDiarmid, R.W. (Ed.). Rare and Endangered Biota of Florida, Volume Three, Amphibians and Reptiles. Gainesville: University Presses of Florida, pp. 50-51.

SHEALY,R.M. 1992.Alabama map turtle.In: Moler,P.E.(Ed.). Rare and endangered biota of Florida. Volume III, amphibians and reptiles. Gainesville: University Press of Florida, pp. 200-203.
SNIDER, A.T. AND BowLER, J.K. 1992. Longevity of reptiles and amphibians in North American collections. Second Edition. Society for the Study of Amphibians and Reptiles, Herpetological Circular No. 21, 40 pp.

WAHLQUIST, H. 1970. Sawbacks of the Gulf Coast. International Turtle and Tortoise Society Journal 4(4):10-13, 28.

Williams, J.D., Bogan, A.E., AND Garner, J.T. 2008. Freshwater mussels of Alabama and the Mobile Basin in Georgia, Mississippi, and Tennessee. Tuscaloosa: University of Alabama Press, 908 pp.

\section{Citation Format for this Account:}

Lovich, J.E., Godwin, J.C., AND McCoy, C.J. 2011. Graptemys ernsti Lovich and McCoy 1992 - Escambia Map Turtle. In: Rhodin, A.G.J., Pritchard, P.C.H., van Dijk, P.P., Saumure, R.A., Buhlmann, K.A., Iverson, J.B., and Mittermeier, R.A. (Eds.). Conservation Biology of Freshwater Turtles and Tortoises: A Compilation Project of the IUCN/SSC Tortoise and Freshwater Turtle Specialist Group. Chelonian Research Monographs No. 5, pp. 051.1-051.6, doi:10.3854/crm.5.051.ernsti.v1.2011, http:// www.iucn-tftsg.org/cbftt/. 